\title{
Efeitos da agressividade infantil para o sofrimento psíquico de professores em diferentes momentos de carreira
}

\author{
Rebeca Eugênia Fernandes de Castro \\ Faculdade Aldeia de Carapicuiba \\ Maria Abigail de Souza \\ Universidade de São Paulo
}

\begin{abstract}
Resumo
O sofrimento de professores tem sido amplamente considerado pela literatura, em associação com diversos fatores. O presente trabalho investiga esse sofrimento sob o aspecto da agressividade vivenciada em sala de aula. Foram entrevistados doze professores de uma escola pública da cidade de São Paulo - onze do sexo feminino e um do sexo masculino - distribuídos em função de três momentos na carreira de ensino: inicial (até seis anos), intermediário (entre doze e dezoito anos) e final (últimos cinco anos da carreira). As entrevistas foram gravadas, transcritas e os dados categorizados conforme a frequência simples de ocorrência. A comparação das respostas revelou diferenças entre os educadores com menor e maior tempo de carreira no ensino: na percepção da agressividade infantil, nos sentimentos despertados e nas estratégias de manejo utilizadas. Frente à constatação dessas diferenças, foi possível refletir e tecer considerações para o delineamento de intervenções preventivas.
\end{abstract}

Palavras-chave: professores; sofrimento; carreira; agressividade.

\begin{abstract}
Effects of children's aggressiveness for the mental suffering of teachers in different moments of career. Teachers' psychological distress has been widely studied in the literature, concerning several factors. This paper investigates the impact of children's aggression in classroom as a source of teachers' distress. Twelve public school teachers from São Paulo city were interviewed - 11 female and 1 male - distributed according to three different stages of the career: initial (1 to 6 years), intermediate (12 to 18 years) and final phase (last 5 years of the career). The interviews were recorded, transcribed and data were categorized considering the simple frequency of occurrence. Data analysis revealed different perceptions of classroom aggression, feelings and management strategies, depending on the phase of the teaching career. From these findings, it was possible to reflect and to present some considerations for outlining preventive interventions.
\end{abstract}

Keywords: teachers; psychological distress; career; aggressiveness.

$\mathrm{N}$ enhuma outra profissão foi tão investigada, avaliada e sistematizada em suas dificuldades e angústias quanto a carreira de professor. Há toda uma literatura especializada em seu sofrimento, caracterizado pela síndrome de burnout, que leva à perda de entusiasmo e ao distanciamento afetivo, aos índices de absenteísmo, aos problemas físicos e psicológicos, além da perda de sentido da profissão (Codo \& Vasques-Menezes, 1999, Guglielmi \& Tatrow, 1998; Maslach \& Jackson, 1981, Zaragoza, 1999).

A síndrome de burnout caracteriza-se por uma exaustão emocional típica das profissões que exigem alguma forma de cuidado com o outro (Farber, 1991, Iwanicki \& Schwab, 1981). Por isso, pode ser compreendida como um fenômeno psicossocial, relacionado à natureza de certas práticas laborativas, que implicam alto nível de dedicação e intenso envolvimento. No caso do ensino, muitos fatores contribuem para o burnout, desde a gestão da sala de aula (turmas grandes, alunos desmotivados, indisciplina), até a falta de reconhecimento e valorização da profissão, passando pelo excesso de aulas e pressões externas ao desempenho profissional, como a falta de tempo, as diversas tarefas burocráticas e a própria organização do trabalho (Gomes et al., 2006, Silva, 2006;).

Segundo a literatura especializada, entre os fatores que contribuem para o sofrimento docente destaca-se a frequência cada vez mais rotineira de episódios de agressividade no ambiente escolar (Batista \& Pinto, 1999, Malagris, 2002). Sua constância e impacto vêm disseminando insegurança, sensação de fracasso, impotência, depressão e ansiedade entre os professores (Anser, Joly, \& Vendramini, 2003, Candau, 1999; Galand, Lecocq, \& Philippot, 2007, Lopes, 2000; Ristum \& Bastos, 2004). Além disso, vêm comprometendo o envolvimento com a atividade de ensino, gerando posturas mais rígidas e intolerantes (Carlotto 
\& Palazzo, 2006, Tricoli, 2002).

Desde meados da década de 90 , as manifestações agressivas observadas no contexto escolar têm despertado a atenção de especialistas de diversas áreas, configurando um objeto de estudo específico: a violência nas escolas (Charlot \& Émin, 1997; Debarbieux, 1998, 1999; Sposito, 2001). Sob essa denominação, encontram-se desde condutas marcadas pela ilegalidade até o descumprimento rotineiro das regras de convívio. Por isso, Charlot (2002) defende uma distinção entre os fenômenos de violência, transgressão e incivilidade: a violência contempla os gestos que infringem a lei com uso da força; a transgressão caracteriza o comportamento contrário às regras da instituição, enquanto a incivilidade refere-se à quebra das regras da boa convivência.

De acordo com o Dicionário de Psicologia da American Psychological Association (American Psychological Association [APA], 2010), o verbete violência corresponde à manifestação de hostilidade/raiva intencional, por meio da força física. $\mathrm{O}$ termo agressividade comporta sentidos diferenciados: assertividade, dominação social, comportamento ameaçador e hostilidade.

Por se tratar de um conceito mais amplo, que pode também assumir uma conotação positiva, o termo agressividade foi adotado no presente trabalho, pois se revela mais condizente com o embasamento teórico desta análise. De acordo com Winnicott (1956/1987,1964/1987), a agressividade constitui uma força vital, que pode ser expressa na infância, com intencionalidade destrutiva, como forma de reivindicar uma perda vivida precocemente. Segundo o pensamento winnicottiano, essa reivindicação, quando não atendida pela família, desloca-se para o espaço escolar, na relação com os professores e cuidadores.

A questão investigada nesta pesquisa refere-se, portanto, aos desdobramentos da agressividade infantil para os professores, à experiência subjetiva de sentir-se agredido. Para tanto, são identificados os comportamentos avaliados como agressivos, os sentimentos despertados e o manejo destas situações. Considerase, nesta análise, o momento da profissão do educador, uma vez que a motivação e o nível de envolvimento pessoal com o ensino passam por vicissitudes (Huberman, 1992), demandando uma intervenção que atenda às fragilidades de cada etapa da carreira.

\section{A agressividade na concepção de Winnicott}

Há três aspectos fundamentais sobre a agressividade na obra de Winnicott, que embasam teoricamente a presente análise: o papel do ambiente

(mãe/família/escola/comunidade/sociedade) para a integração e/ou contenção de impulsos destrutivos; o reconhecimento da esperança existente por trás das manifestações agressivas infantis, que não ocorrem o tempo inteiro, mas nos períodos de confiança na estabilidade do ambiente; e a importância de se admitir e reconhecer o ódio despertado por crianças com condutas antissociais, como forma de expressá-lo objetivamente, neutralizando seus efeitos destrutivos.

Para Winnicott (1939/1987), a agressividade é uma força, em cuja origem não há uma intencionalidade destrutiva (ele exemplifica essa ideia lembrando os chutes do bebê no ventre materno, que revelam essa força, mas não carregam o desejo de ferir). No fluxo do desenvolvimento emocional, a agressividade está relacionada à vitalidade e à potência, sendo esperada sua integração às forças amorosas, para que haja saúde mental e criatividade nas relações com o meio.

Tal processo de integração deve ocorrer ao longo dos primeiros anos de vida, por meio da relação humana mais precoce, que é a díade mãe-bebê. No entanto, eventuais rupturas na sustentação dos cuidados contínuos da criança podem comprometer o fluxo esperado do desenvolvimento. De acordo com Winnicott (1956/1987), são essas falhas ambientais precocemente vivenciadas que levam a criança a manifestar uma tendência antissocial. Comportamentos como furto, mentira e destrutividade na infância expressam, ao mesmo tempo, a vivência de uma perda e a reivindicação para a retomada do desenvolvimento a partir do ponto onde houve a ruptura. Trata-se de exteriorizar o drama de não conseguir administrar o mundo interno, compelindo o ambiente a fazê-lo. Em outras palavras, a tendência antissocial constitui o modo pelo qual a criança força o ambiente a ocupar-se dela, para conter a agressividade que ela própria não consegue integrar, impondo-lhe um sofrimento que passa a ser compartilhado pelo meio. Contudo, o autor ressalta que as manifestações agressivas não emergem o tempo inteiro, mas nos períodos de esperança, quando a estabilidade do ambiente inspira a confiança de que possa haver alguma continência.

A esperança é dirigida inicialmente à figura materna e, em seguida, ao ambiente familiar, podendo estender-se à escola, caso não haja êxito para a retomada do desenvolvimento emocional. Dessa forma, todos os círculos de proteção e socialização da criança tornam-se vulneráveis ao sofrimento representado pela expressão da tendência antissocial. Ela provoca a exaustão, exigindo limites de forma tão intensa e constante que pode até mesmo levar à desistência dos adultos, na forma de abandono ou expulsão. E, se por um lado, o autor enfatiza a necessidade da firmeza e da amorosidade no contato com a criança agressiva, por outro ressalta a importância de reconhecer o ódio mobilizado pela agressividade infantil, posicionandose contrariamente a qualquer forma de sentimentalismo. "Ao que parece, a criança poderá acreditar que é amada somente depois que conseguir sentir-se odiada" (Winnicott, 1947/2000, p. 283). O sentimentalismo, como forma de negação, embute um ódio recalcado, que cedo ou tarde vem à tona, na forma de retaliações e arbitrariedades (Winnicott, 1939/1987). Para o autor, o reconhecimento do ódio permite expressá-lo sem que se perca o controle sobre seus efeitos destrutivos (Winnicott, 1947/2000). Ao mesmo tempo, possibilita um aproveitamento profícuo da agressividade, já que é fonte de vitalidade e potência (Winnicott, 1954/1990).

"Os professores conhecem bem os impulsos agressivos de seus alunos, sejam latentes ou manifestos, e às vezes vêem-se obrigados a enfrentar explosões agressivas ou uma criança que é agressiva" (Winnicott, 1939/1987, p. 89). Mas, de que maneira as condutas agressivas infantis atingem os professores, em sua experiência subjetiva? Que comportamentos são percebidos como agressivos em sala de aula? O tempo de carreira facilita o manejo das situações consideradas agressivas? Essas foram, em linhas gerais, as perguntas norteadoras do presente trabalho, levando-se em conta que a escola é um dos principais ambientes 
depositários da agressividade infantil e, ao mesmo tempo, da esperança por sua continência e transformação. Trata-se de um recorte de caráter qualitativo, cujo objetivo é enfocar os aspectos intrapsíquicos do professor, relacionados ao contato com crianças consideradas agressivas. Um recorte que não visa negar a influência das pressões institucionais, familiares e sociais, também causadoras de sofrimento aos docentes, mas explicitar uma dimensão menos reconhecida do ensino, referente ao universo das emoções e à dinâmica afetiva mobilizada na relação com os alunos que apresentam queixas de comportamento.

\section{Método}

Esta pesquisa foi realizada com doze professores de uma escola pública da periferia do município de São Paulo, com o objetivo de avaliar os tipos de experiências tidas por agressivas, os sentimentos mobilizados e as estratégias de manejo do professor nas diversas situações de confronto, de acordo com seu momento profissional. Considerando o ciclo de vida dos professores descrito por Huberman (1992), foram selecionados quatro professores no início da carreira de ensino (máximo de seis anos), quatro em fase intermediária (entre doze e dezoito anos) e quatro próximos da aposentadoria (últimos cinco anos da carreira), os quais foram entrevistados segundo um roteiro de entrevista semi-dirigida.

A seleção dos professores foi realizada de modo aleatório, após uma palestra explicativa dos objetivos do estudo e critérios de participação. Inicialmente, três professores se apresentaram de forma espontânea. Os demais foram convidados pela pesquisadora (primeira autora), que comparecia de uma a duas vezes por semana na escola. Esses convites foram realizados nos intervalos de aula, em contato pessoal, quando se propunha o agendamento de um horário para a entrevista. Houve apenas uma recusa ao longo da coleta de dados.

Todos os participantes estavam ligados ao Ensino Fundamental, sendo onze professoras do sexo feminino e um professor do sexo masculino, o que reflete a realidade de gênero desta profissão (Instituto Nacional de Estudos e Pesquisas [INEP], 2009) e, mais ainda, a realidade da escola onde foi realizada a pesquisa. Nos três grupos formados em função do tempo de carreira, metade dos professores ensinava para alunos de primeira a quarta séries e metade trabalhava com turmas de quinta a oitava séries.

As entrevistas ocorreram na própria escola, em horários marcados de acordo com a conveniência do professor. A escola cedeu uma sala para as entrevistas, que tiveram duração média de uma hora e meia. As perguntas focalizaram a experiência vivida com turmas de primeira a sexta séries, ou seja, as dificuldades no convívio desses professores com crianças entre sete e doze anos de idade, no intuito de considerar somente as manifestações agressivas infantis. Indagou-se acerca de cinco itens: a) o percurso profissional; b) os comportamentos considerados agressivos observados em sala de aula; c) razões atribuídas a esses comportamentos; d) situações experimentadas como agressivas e os sentimentos despertados; e) estratégias de manejo utilizadas. Nesse artigo, foram privilegiados três desses cinco itens: os comportamentos observados, os sentimentos despertados e as estratégias de manejo.

As entrevistas foram gravadas após explicações e assinatura prévia de Termo de Consentimento Livre e Esclarecido, sendo transcritas minuciosamente, de modo a garantir o máximo de fidedignidade no que diz respeito aos aspectos linguísticos - com o registro da totalidade dos significantes - e paralinguísticos - com a anotação das pausas, omissões de palavras, risos e tonalidade do discurso (Bardin, 1977/2000).

Em relação aos comportamentos observados e estratégias de manejo, as verbalizações dos professores foram categorizadas em função da frequência simples de ocorrência. Na categorização dos sentimentos despertados, consideraram-se não somente as referências explícitas ao tema, mas também aquelas passíveis de identificação pela análise do conteúdo. Estas informações contribuíram para a categorização das respostas, as quais foram reunidas de acordo com a frequência simples de ocorrência, observando-se cada etapa da carreira dos professores entrevistados. As respostas categorizadas foram revisadas pela coautora, para assegurar maior objetividade na classificação. Quanto à interpretação dos dados, esta baseou-se em contribuições psicanalíticas, tendo em vista o referencial winnicottiano de compreensão da agressividade (Winnicott, 1956/1987, 1964/1987) adotado neste trabalho.

Trata-se do resultado de uma pesquisa realizada em nível de mestrado, que buscou elementos para subsidiar uma intervenção preventiva ao sofrimento docente, compreendendo inicialmente as atitudes e manifestações sentidas como ataques a si mesmo ou à sala de aula, bem como os sentimentos mobilizados por estes confrontos. Os diversos aspectos observados ao longo do estudo encontram-se ilustrados por depoimentos dos professores entrevistados, cujos nomes foram cuidadosamente substituídos, a fim de preservar sua imagem e identidade. Suas falas foram apresentadas conforme o método de transcrição adotado, preservando a vivacidade dos relatos e permitindo ao leitor captar a dimensão emocional refletida no discurso. Por isso, o leitor verificará repetições de palavras, omissões (cotadas como [ ]), palavras interrompidas (cotadas com -, ao final da palavra) e pausas (cotadas como ....), além de vícios de linguagem. As edições dos depoimentos realizadas pelas autoras estão cotadas como $[\ldots]$.

\section{Resultados}

\section{Professores em início de carreira - tentativas de com- preensão e aproximação}

Uma das primeiras constatações na análise das entrevistas dos professores iniciantes refere-se à maior facilidade para descreverem suas vivências de agressividade em sala de aula. $\mathrm{O}$ contato com os próprios sentimentos transparece de maneira mais evidente, com demonstrações de maior disponibilidade para relatar as circunstâncias difíceis experimentadas em sala de aula, que são narradas em primeira pessoa.

Um segundo aspecto observado nessa análise mais ampla diz respeito à presença, no discurso de professores iniciantes, de termos relacionados à gestão de resultados na educação. Nesse grupo, a agressividade infantil mobiliza apreensões quanto ao 
cumprimento das metas de ensino e à aplicação de métodos adequados. O discurso apresenta termos como "eficiência", "metas", "metodologia", com visível preocupação quanto à competência pessoal: "O que é que eu tô fazendo? Sou uma professora eficiente?”; "O que me interessa mais é se a criança tá rendendo...quanto à, ao que eu tenho que, que atingir aqui na sala, né?". São termos que não aparecem nas entrevistas de professores que se encontram nas etapas intermediária e final de carreira, embora eles também expressem preocupação com as dificuldades de desenvolver seu trabalho em classe. Zibetti (2004), ao analisar o diário de aula de uma professora em início de carreira, observa a mesma angústia de não corresponder às expectativas do contexto social, de perder a posição e o prestígio. Parece que o tempo e a experiência levam o professor a angustiarse menos com aquilo que se espera dele (metas, competência, eficiência) do que com suas próprias expectativas em relação ao ensino.

Para os professores em início de carreira, as manifestações agressivas infantis mais observadas em classe são (nesta ordem): brigas com agressões físicas entre alunos e perturbação do ambiente, ou seja, o tumulto causado pela agitação de algumas crianças. Esse tumulto traz uma dolorosa sensação de invisibilidade:

Sei lá, eu tô no inferno! [...] O fazer com esses alunos, que era uma, uma, era um..... coisa pegava fogo o tempo todo, o tempo todo eles conversando, sem nenhum respeito pelo, por você ali, que tava querendo dar uma aula, eles...sabe, tavam fazendo mil coisas, menos tá prestando atenção naquilo que você tá falando. Aí você tem que ficar aumentando o tom de voz, aí você aumenta, consegue que eles...parem um pouco, depois tá tudo de novo, fervilhando. (Aline, 3 anos de carreira).

Koyama (1995) descreve o aspecto particular da perda de autoridade em sala como um "apagamento da figura do professor", massacrado pelas falas e condutas dos alunos em classe. Embora essa sensação apareça nos discursos de professores em outros momentos de carreira, entre os iniciantes a descrição das sensações é mais difusa e o discurso traz um tom de espanto, evidenciando a aflição e a necessidade de compreender o fenômeno grupal que é testemunhado em classe. São esses professores que narram tentativas de conversar e negociar com a turma, além de convocar os pais como forma de conhecer o histórico e as condições de seus alunos. Em seus relatos, denotam acreditar que as condutas infantis agressivas com colegas e com as figuras de autoridade no ambiente escolar constituem reflexos do desinvestimento da família na criança e na escola. Mostramse bastante sensíveis ao levantamento de informações sobre a criança, muitas vezes revendo posicionamentos pessoais na relação com os alunos considerados agressivos, após o contato com esses dados.

Os sentimentos expressos pelos docentes a respeito do que é percebido como agressividade em classe passam pela indignação e pela impaciência, embora sempre associados a um certo arrependimento. A entonação dos professores culmina em pesar, como refletem os excertos a seguir: "Chega um momento que (ri)...acho que minha paciência acaba, então eu começo, eu pego, dou-lhe uma bronca, assim, sabe, que eu fico até triste comigo". (Fernanda, 5 anos de carreira).

Com a gente é difícil, porque às vezes você não tem paciência. Você tem 40 dentro da sala, né, todos ali pedindo uma ajuda, você vai fazer o quê? Às vezes a sua inten-, às vezes a nossa intenção não é nem tomar, mas às vezes a gente... põe de castigo, sabe? Às vezes deixa pra lá, deixa passar porque você, às vezes não aguenta, com 40 ali, cada um com uma vida diferente. (Kátia, 6 anos de carreira).

Há também uma impotência entre os professores iniciantes que pode ser observada principalmente pelos sentimentos de menos-valia. Nota-se certa autoculpabilização, como se o fracasso no manejo dos conflitos constituísse uma falha pessoal, despertando desânimo, solidão e abatimento. Por outro lado, observa-se que quanto menor o tempo de ensino, maior a capacidade de renovar a confiança no próprio trabalho e reconstruir o vínculo com a criança considerada agressiva:

Às vezes algum aluno fala alguma coisa pra mim que me deixa...mal, né? Mas eu procuro..não...sabe, no outro dia eu vou, eu chego, eu cumprimento...até pra mostrar pra ele que...sabe, não, não me atingiu ou que...aquela postura dele não foi legal, mas nem por isso eu vou...sacrificá-lo, você entendeu? (Liana, 3 anos de carreira).

Ressalte-se que, nesse grupo, os docentes referem a necessidade de não cultivar ressentimentos, para se manterem a salvo da destrutividade que é mobilizada no convívio com as manifestações da agressividade ("se você ficar alimentando aquilo dentro de você, acho que vem daí esse desgosto, essa dificuldade, né, de, de encarar a sala de aula"). E mencionam algumas estratégias: conversam diretamente com o aluno, buscam negociação com a turma e chamam os pais para tentarem compreender o comportamento infantil. Também costumam lembrar a existência dos outros alunos, ao se sentirem atacados ou confrontados por uma determinada criança; pensam nas condições de vida e na dinâmica familiar em que está inserido o aluno considerado agressivo; afastam-se temporariamente das atividades, por um ou dois dias, e buscam o apoio de outros colegas educadores. São tentativas de restaurar a condição pessoal de trabalho e de impedir a contaminação da prática de ensino por impulsos de retaliação.

\section{Professores em nível intermediário de carreira- amor, ódio e precaução}

Nessa fase, as manifestações agressivas mais observadas pelos professores foram, nesta ordem: brigas com agressão física entre alunos, palavrões e provocações entre as crianças (ofensas, apelidos). Diversas causas são atribuídas a esses comportamentos em classe, desde o desinvestimento familiar em relação aos estudos, até a falta de apoio institucional ao professor e o excesso de direitos assegurados aos alunos. A forma com que os docentes se referem às crianças consideradas agressivas perde em indulgência, enquanto os sentimentos relatados ganham um colorido mais intenso. A impaciência transforma-se em irritação, o cansaço torna-se mais visível, tanto quanto a frustração com o exercício do ensino. Há uma sensação de fracasso, mas diferente daquela mencionada pelos docentes iniciantes, pois 
não traz a conotação de menos-valia. Em virtude do aumento da ambivalência, a ameaça de irrupção da raiva é contida com maior esforço, refletida no desapontamento e na indignação, direcionados ao ambiente. Assim, o fracasso é relacionado a muitos outros fatores, o que posiciona o docente fora do campo da autoculpabilização. Nesse caso, o professor espera maior apoio institucional. Trata-se de uma etapa na qual a agressividade percebida no convívio com os alunos mobiliza questionamentos profundos sobre a escolha e o valor da profissão. "Raiva, claro que dá. Raiva, não, mas fica decepcionado, se sente mal. Sente que...o país tá mal, e os moleques tá pior". (Alex, 18 anos de carreira). "Hoje foi dia que eu dei uma ótima aula. [...] Agora tem dia que, minha filha, você prepara uma aula, você acha que você fracassou como professora. Porque eles não tão nem aí". (Márcia, 12 anos de carreira).

Tem hora que dá raiva mesmo, que você não consegue desenvolv-, acho que não é raiva, você fica bravo, eles perturb-, enche! Não aguenta, você não, não dá! Você não consegue desenvolver nada, aí você se sente um lixo, porque você fala assim, "meu Deus, eu não consigo desenvolver nada, não consigo trabalhar, não consigo fazer nada". Né? (Lídia, 17 anos de carreira).

Esse não conseguir um desenvolvimento do seu conteúdo é uma frustração. Primeiro você fica aí...fica...com faringite, fica se cansando, todo dia, fica estressada, cansada. E daí você pensa: o que que tá tendo de...retorno de tudo isso que você tá fazendo? É mínimo. (Letícia, 17 anos de carreira).

O discurso já parece sinalizar uma atitude reivindicatória que surge gradualmente, um protesto contra a perda de algo vital - o investimento, a valorização, a possibilidade de desenvolver um bom trabalho - além da preocupação (e esperança) de encontrar, no meio externo, alguma saída para a impotência. Por outro lado, também denota maior cisão amor-ódio despertada no contato com as crianças consideradas agressivas, refletida em uma postura que é, ao mesmo tempo, disponível, porém menos tolerante:

Tô tentando dar aula, certo? Ponho o assunto na lousa, falo pra ficar calado, "por favor, por favor, por favor", aí tem aquele aluno que não senta. Fica brincando com um, com outro. Ele começa, né? E vai, brinca, e faz, dá risada, puxa com outro, né, senta, falo pra ele ir pro quadro, não, "então dá licença". Às vezes ele quer isso mesmo. Na verdade, ele queria sair. (Alex, 18 anos de carreira).

Eu não suporto aluno que tá me...tirando da aula toda hora. [...] Uma vez que eu tava na lousa, nessa mesma sala, eles ficaram jogando bolinha de papel, jogando bolinha de papel, enfim jogaram bolinha de papel em mim, quando eu tava escrevendo na lousa. Eu fiz a mesma coisa. Fui pra minha mesa, sentei, falei “eu já fiz isso quando eu tava olhando pra vocês e vocês não queriam parar. Agora eu tô de costas, vocês vão ficar jogando bolinha de papel em mim?! E eu vou levar bolada?! Não. Agora chega. (Letícia, 17 anos de carreira).

Nos relatos, surgem os primeiros sinais da experiência de ingratidão, como revelam estes depoimentos: [...]quando eles te agridem você às vezes não espera, você não quer, você não aceita, né? Porque...eu não agrido os alunos, eu não xingo, eu não falo, então, assim...é, dá, dá um... negócio, parece, pôxa, eu tento tratar eles com... da melhor forma possível e, e, e é isso que eu recebo, não é? (Lídia, 17 anos de carreira).

Eles não têm noção de que cada livro que eles ganham aqui, e esse ano, eles com certeza, no nível 2, ganharam 5 livros. Pelo menos. Novos, que chegaram todos novos. Eles pegam o livro, ficam rodando assim no dedo, cai o livro, (jogam) bolinha de papel [...] (Letícia, 17 anos de carreira).

Não, isso aí que não tem condições é papo furado. Vou dizer uma coisa pra você. Vou dar o exemplo da minha família. Eu estudei numa senhora escola pública, que era assim, de ficar uma semana sem aula. [...] qualquer escola pública em São Paulo, o aluno se quiser, sai bem formado. Porque a escola tem estrutura, a escola de São Paulo tem estrutura. E tem professor. E tem profissional competente pra isso. Falta alguma coisa, não é profissional, nem estrutura. Falta...digamos assim...respeito. No momento principal, que é o momento da passagem dessa função. Essa passagem não tá acontecendo! Que um dos lados não tá permitindo. Que esse lado está impaciente. Se você tem uma dinâmica pra eles, tão a fim de brincar. (Alex, 18 anos de carreira).

Nitidamente, também se observa um sentimento de precaução entre os docentes com maior tempo de ensino. Por isso, os professores nessa fase dão a impressão de manter-se a uma distância segura dos alunos, o que inevitavelmente traz efeitos para a relação em sala de aula:

\footnotetext{
Sabe por que eu não separo mais[ ]? Na gravidez da minha, da minha filha, levei um...soco na barriga. Aí eu falei que não ia mais separar. Aí no começo do ano eu ia e separava tudo. Só que aí...você tem unha. Eu falei, vai que numa dessa eu tô separando e eu arranho e ele chega lá, e fala que foi a professora que arranhou. Então eu comecei a tomar essa postura. (Márcia, 12 anos de carreira).
}

Cada vez que o professor é agredido, ele tem mais medo, assim, ele fica receoso de tentar fazer a mesma coisa aquele dia. Cada agressão que ele sofre, ele fica "eu não guento mais". Ele vai mais preocupado com a agressão do que se não deu o conteúdo. Ele vai se precavendo contra essa agressão.[...] Então ele vai armar outra agressão, e menos preocupado em desenvolver o conteúdo. Então o professor vai se especializando cada vez mais em ...dar um jeito de ficar a classe quieta, ao invés de desenvolver, crescer. (Alex, 18 anos de carreira).

A precaução associada ao desgaste parece influir diretamente na escolha das estratégias de manejo adotadas pelos professores nessa fase. Mais cautelosos, os docentes restringem-se bastante ao uso dos mecanismos institucionais para conterem as condutas agressivas: encaminham o aluno para a coordenação, convocam os pais, efetuam o registro no caderno de ocorrência. Diferentemente dos professores iniciantes, que buscam conversar com os alunos considerados agressivos, na fase intermediária de carreira os docentes afirmam fazer uso da intimidação, ao 
interromperem a aula ou, então, ignorarem o aluno.

\section{Professores próximos da aposentadoria-mágoa, decepção e desesperança}

No final da carreira, as situações agressivas observadas pelos professores envolvem, nesta ordem: o desacato/afronta ao professor, as agressões físicas entre alunos e os palavrões. $\mathrm{O}$ fenômeno da agressividade infantil é percebido de maneira bem mais abrangente e como resultante de causas difusas: influência da mídia, mudanças sociais e culturais.

Huberman (1992) prevê dois encaminhamentos para o final da carreira docente: o conservantismo e o distanciamento afetivo. O primeiro é marcado por lamentações e, o segundo, por um movimento de interiorização e desejo de consagrar mais tempo para si e para outros projetos de vida. Tais posturas foram encontradas entre os docentes entrevistados, evidenciando atitudes mais queixosas ou mais ponderadas ao final do ciclo de vida profissional:

Agora eu acho que o professor tá muito sofrido, muito machucado, por conta da política que tá instalada na educação. Eu às vezes duvido do que, de que tudo isso vai resultar alguma coisa. Quando alguém [ ] aqui fazer pesquisa, eu falo "ah, não quero nem saber". Não vai dar em nada! Vai pra onde isso? Entendeu? Vai servir pra quê? Né? Eu sou muito resistente a isso porque eu sei que não vai dar em nada. Eu quero ver resultado. Eu quero ver que as pessoas venham pra, pra colher dados e levem pra nós, leve para alertar. Do jeito que tá professor nenhum vai aguentar 25 anos, e a aposentadoria, mexeu por quê? (Mara, 28 anos de carreira).

É um momento de vida que a gente tá passando que tá muito difícil mesmo, todo mundo...não sei. Eles não têm muito...eles não têm estrutura de nada, na vida desses meninos daqui. Não têm nada, né? Eles tomam conta de irmãos menores. (Lúcia, 22 anos de carreira).

Embora em um contexto de cansaço e solidão, os professores também demonstram preocupação com as crianças consideradas agressivas, observada na sensação de falência por um trabalho que não pôde ser realizado a contento e pelos prejuízos que já podem ser previstos na vida desses meninos e meninas. Há mágoa e desesperança nos relatos:

Ah, tem dia que eu termino péssima. Ah, larga tudo, sabe, é assim que eu termino o dia às vezes. [...] Tem dia que você sai com dor de cabeça. Você se estressa demais. Sabe, você quer melhorar aquilo lá e você não consegue. (Cristina, 20 anos de carreira).

Mas, ao mesmo tempo, tá difícil porque tá chegando uma hora que todo mundo tá ficando bastante esgotado e sem força. Né? E as pessoas também, o professor também é humano, né, tanto quanto as crianças, tanto quanto qualquer um, e a gente tá sentindo muito sozinho também na situação. (Mara, 28 anos de carreira).

Claramente, o testemunho das mudanças na instituição escolar influencia o modo de perceber e sentir a agressividade infantil nessa etapa da carreira:

Você se sentir impotente, de querer fazer aquilo e não conseguir, de ter uma estrutura que...não sei se....o que que acontece com a estrutura que a ... a criançada foi ficando muito assim, eu acho que foram tirando muito os direitos da escola, de autonomia da escola. (Telma, 22 anos de carreira).

Agora, te garanto que essa turma que volta (refere-se aos professores já aposentados) é a turma que experimentou os meus anos de escola. Com os alunos que eu já vivi. Hoje, nenhum professor mais vai ficar de pé com 15 anos de serviço. Não vai. Não tem estrutura psíquica, emocional que vai aguentar. Porque tá sendo muito grande a carga de bombardeios em cima do professor. (Mara, 28 anos de carreira).

O cansaço parece responsável pela escolha mais limitada das estratégias de manejo dos conflitos, caracterizada pelo uso dos mecanismos institucionais - encaminhamento à coordenação, convocação de pais, registro no caderno de ocorrências. Já não há mais tanta disponibilidade para conversar pessoalmente com as crianças consideradas agressivas, optando-se pela advertência em público ou pelas formas sutis de expulsão: retorno para casa, mudança de sala. $\mathrm{O}$ afastamento da criança representa um alívio, até pelo fato de prevenir o descontrole do professor; por outro lado, faz emergir um sentimento de culpa e fracasso que também é doloroso:

Eu tenho que mandar pra casa?! Não é mandar pra casa, né? Ele tem que ficar aqui. Ele tem que se conscientizar que ele tá aqui, que ele tem que estudar, que ele tem que ser...né? Melhorar pra quarta série. Não é mandar pra casa. Sabe? Então são umas coisas que a gente não, não concorda. A gente faz, mas não concorda (ri). Então a gente fica mal. (Cristina, 20 anos de carreira).

Tem dia que você fica mais irritada mesmo. Primeiro, você dá bronca, chama a atenção várias vezes, não-sei-o-quê. Aí quando não tem jeito mesmo. $\mathrm{O}$ aluno tá lá...impertinente, você tá falando, não sei quê, então...é quando a gente pega e manda pra coordenação. Aí isso é ruim mesmo pra gente. Pro emocional, tudo. Você tá tentando fazer alguma coisa...o aluno tá...e você não pode fazer nada, você não pode pegar o aluno, grudar lá na carteira. (Telma, 22 anos de carreira).

Contrariamente aos professores em outras fases de carreira, não há menção a recursos de âmbito pessoal para suportar o contato com atitudes agressivas, tais como a busca de apoio de colegas ou o levantamento de informações sobre a criança. Mesmo a convocação dos pais, que a princípio ajudaria a compreender melhor o aluno considerado agressivo, pode acabar sobrecarregando emocionalmente o professor, paralisado pela identificação com a impotência dos próprios pais ou responsáveis:

Eles querem que o filho venha, que... que melhore, né? Inclusive às vezes tem mãe até que...a gente chama quando o filho tá dando muito trabalho. Ela até chora... porque... ela também não tá conseguindo fazer com que esse filho atenda, né? [...] em termos gerais as mães, elas...elas pedem mesmo ajuda da gente. "Não, ai...ai, não deixa meu filho se perder, professora, 
[...]Eu só tenho você pra me ajudar". Fica ass-, a gente sente uma carga pesada, meu Deus do Céu. Né? Assim, emocionalmente a gente sente uma carga pesada pra ajudar a pessoa. (Telma, 22 anos de carreira).

No depoimento de Telma, percebe-se claramente o quanto a agressividade em sala de aula revela uma problemática que ultrapassa em muito a dimensão pedagógica. São pais impotentes, que esperam soluções da escola para o comportamento dos filhos, acreditando na figura do professor; crianças ávidas por um tipo de atenção que parece indecifrável ao docente; some-se a isso o cansaço, o desgaste, a descrença, a solidão, a impotência e a mágoa pela falta de reconhecimento, que parecem aumentar ao longo dos anos de ensino; além da vivência dolorosa de uma agressividade pessoal que também é mobilizada, explicitada no desejo de afastar a criança do convívio em sala de aula, apesar de todo o controle racional e consciente dos professores para conter sentimentos de retaliação.

\section{Discussão}

Há diferenças importantes no modo de perceber, sentir e manejar a agressividade em sala de aula, nos distintos momentos da profissão docente. Em relação às expressões consideradas agressivas, nota-se que os professores nos últimos anos de carreira apontam, em primeiro lugar, o desacato/afronta ao professor, antes mesmo das agressões físicas entre alunos, que são destacadas com prioridade pelos docentes nas outras fases da carreira. Parece haver uma vulnerabilidade maior aos ataques pessoais conforme o aumento do tempo de ensino.

Tanto as agressões físicas entre alunos quanto o desacato remetem às conclusões de Koyama (1995), em seu estudo sobre o cotidiano de uma instituição pública de ensino, no qual enfatiza as dificuldades concretas no manejo dos conflitos em classe. $\mathrm{O}$ autor observa que o aluno interioriza uma representação negativa de si mesmo, projetada na forma de agressão aos colegas mais fracos, àqueles que desejam aprender e aos professores.

Quanto aos sentimentos despertados nas situações consideradas agressivas, o relato dos professores iniciantes revela indignação, impaciência, desvalorização e cansaço. A autoculpabilização também é visível, associada ao medo da incompetência, corroborando estudo elaborado por Zibetti (2004). A autoculpabilização é diluída na fase intermediária da carreira, quando os professores começam a questionar a falta de apoio institucional para o manejo das dificuldades na administração da classe. Sentimentos relacionados à agressividade ganham intensidade maior (irritação, raiva), exigindo também uma contenção maior por parte do professor, que se torna mais cauteloso. A experiência de ingratidão começa a surgir, assim como as primeiras referências aos problemas psicossomáticos. Na etapa final da carreira, a preocupação com as crianças agressivas é destacada pelos professores, mas dentro de um contexto de impotência, observando-se sentimentos de mágoa e desesperança.

Dessa forma, há um continuum de sentimentos desagradáveis na experiência docente, o qual segue um movimento oposto ao exibido pelas crianças, cuja agressividade reflete a esperança de que seu pedido de ajuda e continência (Winnicott, 1956/1987) encontra-se acolhida no ambiente escolar, já que isso não lhe foi proporcionado junto à família. À medida que o tempo passa, essas crianças manifestam com mais vigor sua tendência antissocial, na esperança de continência, mas os professores com mais tempo de carreira, já extenuados, sem compreender essa demanda infantil, acabam tornando-se mais refratários a um encontro ou diálogo, tendência positiva observada nos professores iniciantes. Essa hostilidade crescente de ambas as partes leva à desesperança, refletida não só na impotência, mas na perda da flexibilidade e da criatividade diante de situações de confronto. Nas etapas intermediária e final de carreira, o manejo da agressividade torna-se cada vez mais restrito aos mecanismos institucionais.

Vários estudos apresentam evidências de que a prática docente não se encontra imune a sentimentos destrutivos, como aversão e raiva (Collingridge, 2008, Cordié, 1998), nem está livre dos efeitos do tempo (Gomes et al., 2006), contribuindo para alimentar a agressividade na escola, devido à intolerância crescente (Koehler, 2003, Tricoli, 2002). Portanto, não há como negligenciar a importância de um cuidado contínuo aos professores durante a carreira, que ajude a manter a flexibilidade e a capacidade criativa dos primeiros anos, sem permitir a invasão dos sentimentos de menos-valia e fracasso que confundem os docentes iniciantes.

Essas constatações decorrentes da análise das entrevistas dos professores mostram a importância de reavaliar as condições institucionais de suporte ao educador, considerando a especificidade da natureza do trabalho docente, que necessariamente exige dedicação e envolvimento com os alunos. Ou seja, a escola não pode se limitar a exigir formação continuada em termos pedagógicos ou atualização de conhecimentos sobre as últimas teorias e propostas educativas.

A adoção de alternativas de intervenção que contemplem os aspectos emocionais da profissão vem sendo enfatizada por diversos autores. Carloto (2002), por exemplo, aponta o quanto o professor encontra-se preparado para decidir o que e como ensinar, em detrimento do conhecimento de seus alunos e de si mesmo. Meleiro (2002), analisando a síndrome de burnout, sugere uma lista de estratégias de enfrentamento que podem ser adotadas pelos professores, implicando desde cuidados com o sono e a alimentação até o esforço pessoal para tornar-se menos exigente e perfeccionista no exercício profissional. Gomes et al (2006) defendem a adoção de estratégias de apoio institucional aos docentes, por meio de sistemas de ajuda entre pares, treino cognitivo e comportamental para o gerenciamento do estresse e problemas encontrados em sala de aula, além de métodos de ensino adaptados a alunos com dificuldades de aprendizagem e análise das condições da escola e do ensino que dificultam a ação docente.

Partindo do recorte do presente estudo, que enfatiza a dinâmica intrapsíquica mobilizada pela agressividade infantil em sala de aula, os resultados encontrados permitem destacar alguns aspectos a serem considerados em uma intervenção com professores. O primeiro refere-se à mudança de cultura no ambiente escolar, ou seja, a agressividade permeia a relação com crianças consideradas agressivas, trazendo sentimentos 
destrutivos. Não se trata de legitimar a agressividade na prática docente, mas atentar para o fato de que o ensino ocorre no contexto de uma relação humana, portanto, vulnerável a todas as emoções. Conforme esclarece Winnicott (1939/1987), a negação de tais sentimentos reflete-se, posteriormente, na emergência de um ódio recalcado, muito mais destrutivo.

O segundo aspecto consiste no engajamento da escola para a realização da proposta aqui descrita. Isso significa que uma intervenção com professores deve ser adotada como um investimento na formação do quadro docente, sinalizando a compreensão de que a natureza do trabalho do professor exige um espaço para a depuração e a reflexão a respeito das emoções despertadas em classe. Esse espaço estaria voltado ao compartilhamento e discussão sobre os sentimentos mobilizados no contato com as manifestações agressivas, ajudando os educadores a pensarem no significado da agressividade, nas suas próprias reações, nos possíveis desejos de punição que escapam ao controle racional, as alternativas de manejo adotadas e possíveis, sem julgamento ou expectativa de que sejam totalmente responsáveis pelo controle da turma. Conversar sobre a agressividade como elemento próprio do humano fornece condições para os docentes ponderarem sobre seu papel em um eventual círculo vicioso de retaliação em sala de aula (Tricoli, 2002). Também desenvolve o senso de responsabilidade sobre essa dinâmica, auxiliando o docente a sair de uma posição de impotência e desesperança.

Um terceiro aspecto a ser observado para uma intervenção refere-se à busca de sentido para as atitudes agressivas infantis. Observou-se, ao longo desta pesquisa, que alguns docentes alcançam um apaziguamento da hostilidade contra as crianças percebidas como agressivas ao investigarem sua história de vida ou mesmo imaginarem as condições e riscos aos quais estão expostas. Internamente, esses professores se ocupam dessas crianças de um modo compreensivo, o que produz efeitos qualitativamente diferentes na acomodação dos conflitos experimentados. A reflexão sobre a história e as perspectivas de vida da criança agressiva abre possibilidades de tolerar e transformar os agravos sofridos pelo docente. Com isso, a atualização dos vínculos é favorecida, possibilitando o reconhecimento do potencial dessas crianças, suas qualidades e as restrições do contexto em que estão inseridas.

Não se pode esquecer ainda a importância de elaboração das perdas existentes em toda profissão, dadas as diversas menções dos professores sobre a experiência da escola em décadas passadas. Como qualquer outro segmento da cultura, a Educação também está sujeita a transformações e, com isso, às alterações de significados, papéis e formas de atuação dos professores. Oferecer oportunidades de reflexão sobre as mudanças vividas ao longo da carreira pode favorecer a aceitação e superação das perdas que inevitavelmente acontecem, e a reapropriação dos ganhos e do amadurecimento trazidos pela experiência.

\section{Considerações Finais}

A agressividade infantil, conforme a teoria winnicottiana, sinaliza um quadro de sofrimento vivido pela criança, que compele o ambiente a ocupar-se dela - incluindo o ambiente escolar - na medida em que há uma esperança de continência. Ao exteriorizar esse sofrimento, ela inflige dor aos que a cercam. Verificou-se no presente trabalho o quanto os professores são desafiados na administração das situações reais provocadas em sala de aula, mas principalmente no manejo dos sentimentos desencadeados pela vivência contínua de reiterados confrontos.

O sofrimento dos professores emerge de diferentes maneiras, de acordo com a fase de carreira vivida pelo docente. O tempo de ensino é uma variável importante em um processo de intervenção. A angústia dos primeiros anos de carreira é associada a uma flexibilidade criativa e mais potente - embora dolorosa - do que a experiência dos professores mais antigos, enrijecidos pelo desgaste e pela contenção da hostilidade despertada por essas crianças. Ao final da carreira, não deixam de se preocupar com os alunos agressivos, mas a impotência e a mágoa evidenciam desesperança. Nesse sentido, a trajetória do sofrimento docente segue movimento oposto àquele apresentado pela criança agressiva: esta expressa sua tendência antissocial para adultos cada vez menos esperançosos, porque ainda tem esperança.

Alternativas de intervenção com os professores já vêm sendo ressaltadas pela literatura, observando-se a importância do investimento nos aspectos emocionais da profissão docente. Entende-se que esse estudo traz como contribuições a um processo de intervenção o reconhecimento da agressividade mobilizada no professor e a responsabilidade institucional de oferecer um espaço de atenção às emoções, como parte da formação docente.

Espera-se que o presente trabalho possa ampliar a compreensão das expressões afetivas subjacentes à relação professor-aluno, colaborando para o entendimento da delicada posição dos professores e seu importante papel na construção de relações mais harmoniosas em sala de aula. E que possa, principalmente, estimular propostas de intervenção no ambiente escolar, de modo a promover o fortalecimento dos professores, incumbidos de transmitir um legado cultural às crianças e de auxiliá-las a se tornarem responsáveis por esse legado, no cuidado de si mesmas, do outro e do mundo.

\section{Referências}

American Psychological Association. (2010). Dicionário de Psicologia. Porto Alegre: Artmed.

Anser, M. A. C. I., Joly, M. C. R. A., \& Vendramini, C. M. M. (2003). Avaliação do conceito de violência no ambiente escolar: visão do professor. Psicologia: Teoria e Prática, 5(2), 67-81.

Bardin, L. (2000). Análise de conteúdo. Lisboa: Edições 70. (Obra original publicada em 1977)

Batista, A. S., \& Pinto, R. M. (1999). Segurança nas escolas e burnout dos professores. In W.Codo (Org.), Educação: Carinho e Trabalho (pp. 312332). Petrópolis, RJ: Vozes.

Candau, V. (1999). Escola e violência. Rio de Janeiro: DP\&A Editora.

Carlotto, M. S. (2002). A síndrome de burnout e o trabalho docente. Psicologia em Estudo, 7(1), 21-29.

Carlotto, M. S., \& Palazzo, L. S. (2006). Síndrome de burnout e fatores associados: um estudo epidemiológico com professores. Cadernos de Saúde Pública, $22(5), 1017-1026$.

Charlot, B. (2002). A violência na escola: como os sociólogos franceses abordam 
essa questão. Sociologias, 8, 432-443.

Charlot, B., \& Émin, J.C. (1997). Violences à l'école. État des savoirs. Paris: Armand Colin.

Codo, W., \& Vasques-Menezes, I. (1999). O que é burnout? In W. Codo (Org.), Educação: Carinho e Trabalho (pp. 237-254). Petrópolis, RJ: Vozes.

Collingridge, D. S. (2008). Phenomenological insight on being hindered from fulfilling one's primary responsibility to educate students. The Alberta Journal of Educational Research, 54(1), 112-123.

Cordié, A. (1998). Malestar en el docente: la educación confrontada com el psicoanálisis. Buenos Aires: Ediciones Nueva Visión.

Debarbieux, E. (1998). Le professeur et le sauvageon: violence à l'école, incivilité et postmodernité. Revue Française de Pédagogie, 123, 7-19.

Debarbieux, E. (1999). La violence en milieu scolaire-le désordre des choses. Paris: ESF.

Farber, B. A. (1991). Crisis in education. Stress and burnout in the american teacher. São Francico: Jossey-Bass Inc.

Galand, B., Lecocq, C., \& Philippot, P. (2007). School violence and teacher professional disengagement. British Journal of Educational Psychology, 77, 465-477.

Gomes, A R., Silva, M. J., Mourisco, S., Silva, S., Mota, A., \& Montenegro, N. (2006). Problemas e desafios no exercício da atividade docente: um estudo sobre o estresse, "burnout", saúde física e satisfação profissional em professores do $3^{\circ}$ ciclo e ensino secundário. Revista Portuguesa de Educação, 19(1), 67-93.

Guglielmi, R. S., \& Tatrow, K. (1998). Occupational stress, burnout, and health in teachers: a methodological and theoretical analysis. Review of Educational Research, 68(1), 61-69.

Huberman, M. (1992). O ciclo de vida profissional dos professores. In A. Nóvoa (Org.), Vidas de professores (pp. 31-62). Lisboa: Porto Editora.

Instituto Nacional de Estudos e Pesquisa Anísio Teixeira. (2009). Sinopses estatísticas da educação básica - Sinopse do professor. Recuperado de http:// inep.gov.br/basica/censo/Escolar/Sinopse/sinopse.asp

Iwanicki, E. F., \& Schwab, R. L. (1981). A cross validation study of the Maslach Burnout Inventory. Educational and Psychological Measurement, 41, 1167-1174.

Koehler, S. M. F. (2003). Violência psicológica: um estudo do fenômeno na relação professor-aluno. (Dissertação de Mestrado não publicada). Universidade de São Paulo, São Paulo.
Koyama, M. A. F. (1995). Confrontos no ensino: um estudo psicossocial em situações concretas. (Dissertação de Mestrado não publicada). Universidade de São Paulo, São Paulo.

Lopes, C. S. (2000). Violência e trabalho escolar. Teoria e Prática da Educação, 3(6), 91-113.

Malagris, LE. N. (2002). O professor, o aluno com distúrbio de conduta e o stress. In M. E. N. Lipp (Org.), O stress do professor (pp. 41-53). São Paulo: Papirus.

Maslach, C., \& Jackson, S. E. (1981). The measurement of experienced burnout. Journal of Occupational Behavior, 2, 99-113.

Meleiro, A. M. A. S. (2002). O stress do professor. In M. E. N. Lipp (Org.), $O$ stress do professor (pp. 11-27). São Paulo: Papirus.

Ristum, M., \& Bastos, A. C. S. (2004). Violência urbana: uma análise dos conceitos de professores do ensino fundamental. Ciência e Saúde Coletiva, 9(1), 225-239.

Silva, M. E. P. (2006). Burnout: por que sofrem os professores? Estudos e pesquisas em Psicologia, 6(1), 89-98.

Sposito, M. P. (2001) Um breve balanço da pesquisa sobre violência escolar no Brasil. Revista Educação e Pesquisa, 27(1), 87-103.

Tricoli, V. A C. (2002). O papel do professor no manejo do stress do aluno. In M. E. N. Lipp (Org.), O stress do professor (pp. 90-106). São Paulo: Papirus.

Winnicott, D. W. (1987). Agressão. In D. W. Winnicott (Org.), Privação e Delinqüência (pp. 89-96). São Paulo: Martins Fontes. (Obra original publicada em 1939)

Winnicott, D. W. (2000). O ódio na contratransferência. In D. W. Winnicott (Org.), Da Pediatria à Psicanálise (pp. 277-287). Rio de Janeiro: Imago. (Obra original publicada em 1947)

Winnicott, D. W. (1990). Natureza humana. Rio de Janeiro: Imago. (Obra original publicada em 1954)

Winnicott, D. W. (1987). A tendência anti-social. In D. W. Winnicott (Org.), Privação e Delinqüência (pp. 127-137), São Paulo: Martins Fontes. (Obra original publicada em 1956)

Winnicott, D. W. (1987). Raízes da agressão. In D. W. Winnicott (Org.), Privação e Delinqüência (pp. 96-103). São Paulo: Martins Fontes. (Obra original publicada em 1964)

Zaragoza, J. M. E. (1999) O mal-estar docente: a sala de aula e a saúde dos professores. Bauru, SP: Edusc.

Zibetti, M. L. T. (2004). A angústia no ofício de professor. Psicologia Escolar e Educacional, 8(2), 219-225.

Rebeca Eugênia Fernandes de Castro, mestre em Psicologia Clínica pelo Instituto de Psicologia da Universidade de São Paulo, é professora na Faculdade Aldeia de Carapicuíba. Endereço para correspondência: Av Comandante Sampaio, 755, apt 81, Km 18, Osasco, SP. CEP 06192-010. Telefones (11) 36813666 e 980432870.E-mail: rebecaeugenia@usp.br

Maria Abigail de Souza, pós-doutora pela Universidade Paris V, doutora em Psicologia Clínica pela Universidade de São Paulo, é professora titular no Instituto de Psicologia da Universidade de São Paulo. E-mail:abigail@usp.br 